\title{
Development of a photochemical source for the production and calibration of acyl peroxynitrate compounds
}

\author{
P. R. Veres ${ }^{1,2}$ and J. M. Roberts ${ }^{2}$ \\ ${ }^{1}$ Cooperative Institute for Research in Environmental Sciences, University of Colorado, Boulder, Colorado, USA \\ ${ }^{2}$ Chemical Sciences Division, NOAA Earth System Research Laboratory and Cooperative Institute for Research in \\ Environmental Sciences, Boulder, CO, USA
}

Correspondence to: P. R. Veres (patrick.veres@ noaa.gov)

Received: 8 January 2015 - Published in Atmos. Meas. Tech. Discuss.: 3 February 2015

Revised: 4 May 2015 - Accepted: 5 May 2015 - Published: 29 May 2015

\begin{abstract}
A dynamic system for the calibration of acyl peroxynitrate compounds (APNs) has been developed in the laboratory to reduce the difficulty, required time, and instability of laboratory-produced standards for difficult-to-synthesize APN species. In this work we present a photochemical source for the generation of APN standards: acetyl peroxynitrate (PAN), propionyl peroxynitrate (PPN), acryloyl peroxynitrate (APAN), methacryloyl peroxynitrate (MPAN), and crotonyl peroxynitrate (CPAN). APNs are generated via photolysis of a mixture of acyl chloride $(\mathrm{RC}(\mathrm{O}) \mathrm{Cl})$ and ketone $(\mathrm{RC}(=\mathrm{O}) \mathrm{R})$ precursor compounds in the presence of $\mathrm{O}_{2}$ and $\mathrm{NO}_{2}$. Subsequent separation by a prep-scale gas chromatograph and detection with a total $\mathrm{NO}_{y}$ instrument serve to quantify the output of the APN source. Validation of the APN products was performed using iodide ion chemical ionization mass spectroscopy (I- CIMS). This method of standard production is an efficient and accurate technique for the calibration of instrumentation used to measure PAN, PPN, APAN, MPAN, and CPAN.
\end{abstract}

\section{Introduction}

Peroxycarboxylic nitric anhydrides, or acyl peroxynitrates (APNs), have long been considered important atmospheric constituents (Roberts, 1990, 2007; Stephens, 1987). Often the most abundant odd nitrogen species, e.g., $\mathrm{NO}_{y}\left(\mathrm{NO}+\mathrm{NO}_{2}+\mathrm{NO}_{3}+2 \mathrm{~N}_{2} \mathrm{O}_{5}+\mathrm{HNO}_{3}+\mathrm{HONO}+\right.$ $\mathrm{HO}_{2} \mathrm{NO}_{2}+$ APNs + organic nitrates $+\ldots$ ), in the atmosphere, APNs play an integral part of ozone photochemistry in remote regions (Singh et al., 1992; Roberts, 1990,
2007) as byproducts of the reaction of $\mathrm{NO}_{x}\left(\mathrm{NO}+\mathrm{NO}_{2}\right)$ and volatile organic compounds (VOCs). Thermal decomposition of APNs, on a timescale of hours to months, is often the most dominant atmospheric sink and results in release of $\mathrm{NO}_{x}$. APNs, as a $\mathrm{NO}_{x}$ reservoir, therefore serve as an important pathway for transport of $\mathrm{NO}_{x}$ to remote regions (Moxim et al., 1996; Horowitz and Jacob, 1999).

The most atmospherically abundant and well-understood of the APNs is acetyl peroxynitrate $\left(\mathrm{PAN}, \mathrm{CH}_{3} \mathrm{C}(\mathrm{O}) \mathrm{O}_{2} \mathrm{NO}_{2}\right.$ ) formed from the oxidation of VOCs (Roberts, 2007; Fischer et al., 2014; Singh et al., 1992; LaFranchi et al., 2009; Moxim et al., 1996; Phillips et al., 2013; Roberts et al., 2004, 2007; Williams et al., 1997). Recent research has become increasingly focused on less-well-studied APNs due to their involvement in several key atmospheric processes. Of these, interest has been generated for acryloyl peroxynitrate (APAN, $\mathrm{CH}_{2} \mathrm{CHC}(\mathrm{O}) \mathrm{O}_{2} \mathrm{NO}_{2}$ ), a product of acrolein oxidation, where the dominant atmospheric source is understood to be from aged biomass burning emissions (Yokelson et al., 2009). Methacryloyl peroxynitrate (MPAN, $\mathrm{CH}_{2} \mathrm{C}\left(\mathrm{CH}_{3}\right) \mathrm{C}(\mathrm{O}) \mathrm{O}_{2} \mathrm{NO}_{2}$ ) has received recent attention due to its involvement as an intermediate in secondary organic aerosol formation from isoprene (Surratt et al., 2010). propionyl peroxynitrate (PPN) - formed from precursors such as propanal, 1-butene, and alkanes (Williams et al., 1997; Roberts et al., 2001) - is understood to be a tracer for anthropogenic photochemistry, as biogenic precursors are expected to be a negligible source.

A multitude of techniques have been employed for routine measurement of atmospheric APNs since the middle of the 20th century. The oldest and most widely used of these 
techniques is gas chromatography (GC) coupled to a detection method such as (i) electron capture (Darley et al., 1963; Williams et al., 2000; Flocke et al., 2005; Schrimpf et al., 1995; Roberts et al., 2006; Roberts, 1990), (ii) chemiluminescence (Gaffney et al., 1998), or (iii) mass spectrometry (Tanimoto et al., 1999). Liquid chromatography has also been used for the measurement of PAN, with limited results (Grosjean et al., 1991). Optical techniques such as Fourier transform infrared spectroscopy (FTIR; Tuazon et al., 1978) and thermal-dissociation laser-induced fluorescence (TDLIF; Wooldridge et al., 2010) have been employed with more recent developments, such as cavity ring-down spectroscopy (Paul et al., 2009), showing promise as fast-response measurement techniques.

Among the newer methods gaining traction are mass spectrometric techniques, such as chemical ionization mass spectrometry, CIMS (Hastie et al., 2010; Hansel and Wisthaler, 2000; Huey, 2007). An increasingly popular method is thermal-dissociation chemical ionization mass spectrometry (TD-CIMS) for the measurement of APNs (Slusher et al., 2004; Phillips et al., 2013; Zheng et al., 2011). Comparisons of the TD-CIMS method with other techniques, such as GC and TD-LIF, show reasonably good agreement (Wooldridge et al., 2010; Tyndall et al., 2005). However, there exists the potential for various interferences, such as peroxy acetic acid and carboxylic acids, requiring additional consideration (Phillips et al., 2013).

Detection sensitivity is not inherently deducible from the TD-CIMS method; rather it is a function of the thermaldissociation efficiency, ion transmission, and inlet losses; therefore calibration is a necessary requirement in order to perform accurate, quantitative measurements. A multitude of APN calibrations procedures have been developed over the years, with the earliest examples focused exclusively on the synthesis and calibration to PAN, with later methods expanded to include additional APN species. Currently there exist two widely used synthesis methods, wet chemical synthesis (Kravetz et al., 1980; Nielsen et al., 1982) followed by purification (Gaffney et al., 1984; Holdren and Spicer, 1984; Ciccioli et al., 1992) and online photoproduction (Furgeson et al., 2011; Grosjean et al., 1984; Warneck and Zerbach, 1992a; Joos et al., 1986; Grosjean and Harrison, 1985). While both methods are effective, the amount of time, difficulty, and hazards involved in the wet chemical handling, storage, and disposal make it a less-desirable approach. Online photoproduction of APNs, however, offers a more rapid alternative with significantly reduced complexity in comparison to wet chemical synthesis methods.

In this work, we present a new, dynamic photochemical source for the production of PAN, PPN, APAN, MPAN, and CPAN in the laboratory. The method developed here relies on the photolysis of acyl chloride $(\mathrm{RC}(\mathrm{O}) \mathrm{Cl})$ compounds or ketones $(\mathrm{RC}(=\mathrm{O}) \mathrm{R})$ in the presence of $\mathrm{O}_{2}$ and $\mathrm{NO}_{2}$ resulting in the formation of various APNs. Results will be shown validating the production of APAN, MPAN, and CPAN from acyl chloride precursors through the use of preparatory-scale GC and subsequent detection with both $\mathrm{a} \mathrm{NO}_{y}$ detector and a TDCIMS using $\mathrm{I}^{-}$primary ions $\left(\mathrm{I}^{-}\right.$CIMS). Production of PAN and PPN, via photolysis of acetone and 3-pentanone, respectively (Furgeson et al., 2011; Warneck and Zerbach, 1992a; Volz-Thomas et al., 2002), will also be shown. A brief discussion on APN sensitivity as a function of inlet dissociation temperature will also be provided.

\section{Methods}

Figure 1 shows a simplified schematic of the photolysis source used in this work. This photolysis source is similar to that used in previous photo-based PAN calibration methods (Furgeson et al., 2011). In fact, the production of PAN and PPN used here has been described previously using the respective precursor compounds acetone and 3-pentanone (Furgeson et al., 2011; Warneck and Zerbach, 1992a; VolzThomas et al., 2002). In this work we show a new method for the online synthesis of APAN, MPAN, and CPAN using acryloyl chloride, methacryloyl chloride, and crotonyl chloride precursor compounds, respectively. Precursor compounds are diluted with tridecane, in the ratios reported in Table 1 according to their volatility, and placed into a glass diffusion cell with a headspace flow of $20 \mathrm{sccm}$ zero air. The outflow of the diffusion cell is mixed with approximately $5 \mathrm{sccm}$ of a 5 ppmv $\mathrm{NO}_{2}$ mixture. The mixture is photolyzed using a $254 \mathrm{~nm}$ Pen-Ray ${ }^{\circledR}$ lamp in a fused silica cell, with a residence time of approximately $6 \mathrm{~min}$. Photolysis of acyl chloride precursors in the presence of $\mathrm{O}_{2}$ and $\mathrm{NO}_{2}$ proceed via the following reactions:

$$
\begin{aligned}
& \mathrm{RC}(\mathrm{O}) \mathrm{Cl} \stackrel{\Delta}{\longrightarrow} \mathrm{RC}(\mathrm{O})^{\bullet}+\mathrm{Cl}^{\bullet}, \\
& \mathrm{RC}(\mathrm{O})^{\bullet}+\mathrm{O}_{2} \longrightarrow \mathrm{RC}(\mathrm{O}) \mathrm{O}_{2}^{\cdot}, \\
& \mathrm{RC}(\mathrm{O}) \mathrm{O}_{2}^{\cdot}+\mathrm{NO}_{2} \longrightarrow \mathrm{RC}(\mathrm{O}) \mathrm{O}_{2} \mathrm{NO}_{2} .
\end{aligned}
$$

Resulting APN products are subsequently separated using a prep-scale GC similar to that described by Flocke et al. (2005). Flow from the photolysis cell is injected onto an Rtx-200 gas chromatography column $(15 \mathrm{~m}, 0.53 \mathrm{~mm}$ inside diameter, $1.5 \mu \mathrm{m}$ ) and held at a temperature of $30^{\circ} \mathrm{C}$ with a helium carrier gas flow of $10 \mathrm{sccm}$. The column effluent is analyzed using both a $\mathrm{NO}_{y}$ analyzer and $\mathrm{I}^{-}$CIMS.

$\mathrm{NO}_{y}$ was quantified using a laboratory-built analyzer that converts PAN to NO on a molybdenum tube followed by chemiluminescence detection (Ridley and Howlett, 1974; Fehsenfeld et al., 1987). The conversion efficiency of the $\mathrm{NO}_{y}$ instrument used in this study was approximately $96 \%$ with a sensitivity of $4.07 \pm 0.08 \mathrm{~Hz} \mathrm{pptv}^{-1}$.

A detailed description of the $\mathrm{I}^{-}$CIMS is presented elsewhere (Slusher et al., 2004). Briefly, APNs are dissociated in a heated inlet, subsequently react with iodide ions $\left(\mathrm{I}^{-}\right)$, and are detected as carboxylate anions using a quadrupole mass 
Table 1. Summary of calibration factors $\left(\mathrm{CFs}, \mathrm{Hz} \mathrm{pptv}^{-1}\right)$ relative to PAN using results from the calibration mixture. The mix ratio represents the volumetric mixing ratio of precursor compound to tridecane used and is held constant for both single-component mixtures and multicomponent mixtures.

\begin{tabular}{llrrrr}
\hline Analyte & Precursor & Mix & $\mathrm{CF}_{\text {norm }}^{\mathrm{a}}$ & $\mathrm{CF}_{\text {rel }}^{\mathrm{b}}$ & $\begin{array}{r}\mathrm{DL}, \\
\text { pptv }\end{array}$ \\
\hline PAN & Acetone & & $13.3 \pm 0.4$ & 1 & 2.8 \\
APAN & Acryloyl chloride & $1: 45$ & $12.8 \pm 1.4$ & $0.97 \pm 0.08$ & 2.8 \\
PPN & 3-Pentanone & $1: 11$ & $13.1 \pm 2.3$ & $0.95 \pm 0.15$ & 1.9 \\
MPAN & Methacryloyl chloride & $1: 11$ & $1.3 \pm 0.1$ & $0.10 \pm 0.01$ & 21 \\
cis-CPAN & Crotonyl chloride & $1: 11$ & $3.9 \pm 0.6$ & $0.29 \pm 0.04$ & 7.0 \\
trans-CPAN & Crotonyl chloride & $1: 11$ & $7.1 \pm 0.4$ & $0.53 \pm 0.04$ & 3.8 \\
\hline
\end{tabular}

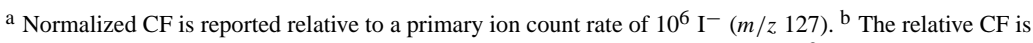
defined as the instrumental sensitivity of each APN relative to the PAN sensitivity. ${ }^{\mathrm{c}}$ Detection limits determined from the standard deviation in the instrument background are reported at the $3 \sigma$ level.

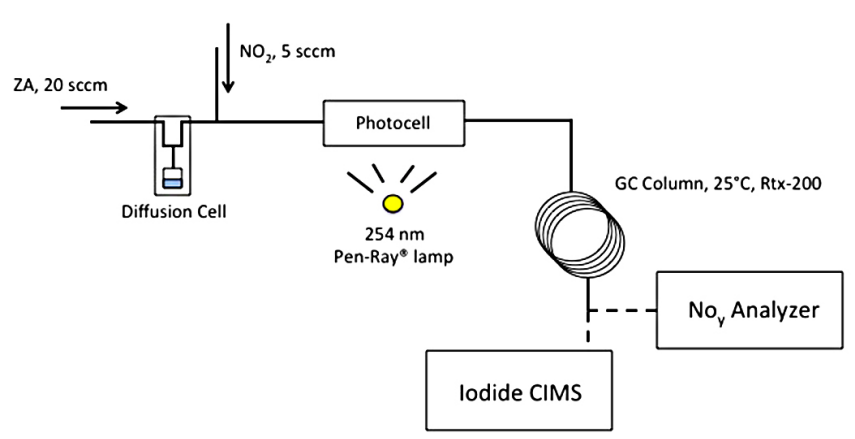

Figure 1. Shown is a schematic of the photochemical calibration system used in this work for the production of APNs with subsequent detection using a total $\mathrm{NO}_{y}$ detector and an iodide ion TDCIMS.

analyzer:

$$
\begin{aligned}
& \mathrm{RC}(\mathrm{O}) \mathrm{O}_{2} \mathrm{NO}_{2} \stackrel{\Delta}{\longrightarrow} \mathrm{RC}(\mathrm{O}) \mathrm{O}_{2}+\mathrm{NO}_{2}, \\
& \mathrm{RC}(\mathrm{O}) \mathrm{O}_{2}+\mathrm{I}^{-} \longrightarrow \mathrm{RC}(\mathrm{O}) \mathrm{O}^{-}+\mathrm{IO} .
\end{aligned}
$$

Iodide ions are generated via the electron attachment reaction of $\mathrm{CH}_{3} \mathrm{I}$ in a ${ }^{210} \mathrm{Po}$ ionizer. A critical orifice was used to maintain an inlet flow of $2.2 \mathrm{slpm}$ at a flow tube pressure of 50 mbar. A switchable inlet was used for sampling through a heated dissociator to allow detection of APNs via Reactions (R1) and (R2), or a "cold" $\left(30^{\circ} \mathrm{C}\right)$ inlet, to serve as an instrumental background. Unless otherwise stated, the inlet dissociator temperature was set to $150^{\circ} \mathrm{C}$ for the experiments presented in this work. In response to a well-known dependence of PAN detection on the water concentration in the flow tube (Slusher et al., 2004), a $100 \%$ relative humidity, $10 \mathrm{sccm} \mathrm{N} \mathrm{N}_{2}$ flow was added directly to the flow tube. The instrument was tuned to minimize the detection of cluster ions such that the observed $\mathrm{I}^{\bullet} \mathrm{H}_{2} \mathrm{O}^{-}: \mathrm{I}^{-}$ratio was 0.002 .

\section{Results}

\subsection{Acyl peroxynitrate (APNs) synthesis and calibration}

Precursor compounds were individually diluted with tridecane in the ratios reported in Table 1 and placed into glass diffusion cells. As discussed in Sect. 2, flow from the diffusion cell is mixed with $\mathrm{NO}_{2}$, photoreacted, GC-separated, and sampled with the $\mathrm{NO}_{y}$ instrument and $\mathrm{I}^{-}$CIMS. An example chromatogram, detected using $\mathrm{I}^{-}$CIMS, is shown in the bottom four panels of Fig. 2 for each single-component mixture. The data are displayed as $m / z$ observed with respect to retention time.

In all four single-precursor mixtures, PAN production was also observed as a product. One plausible explanation for the observation of PAN formation is derived from the sample preparation methods employed. Acetone is applied as a rinsing and drying reagent for the glass diffusion cells of which there is likely a residual amount in the cell after cleaning. This residual acetone will react with $\mathrm{NO}_{2}$ in the presence of oxygen to form PAN when irradiated by a UV light source (Warneck and Zerbach, 1992b; Volz-Thomas et al., 2002). The presence of a similar amount of PAN in each singlecomponent mixture, chloride and ketone precursors alike, is consistant with PAN production via the contaminant.

According to the expected $\mathrm{I}^{-}$CIMS ion chemistry, PAN $(m / z$ 59), APAN $(m / z 71)$, and PPN $(m / z 73)$ are detected at unique $m / z$ ratios. MPAN $(m / z$ 85) and CPAN $(m / z 85)$, however, yield isobaric products and are therefore inseparable using $\mathrm{I}^{-}$CIMS. Aside from the previously discussed PAN production, photoproduction of PPN, APAN, and MPAN all yield a single product ion as expected. However, in the case of the CPAN source, via crotonoyl chloride, two peaks are observed at $m / z 85$ eluding at different retention times $\left(t_{\mathrm{r}} \sim 9\right.$ and $\left.14 \mathrm{~min}\right)$. It is our belief that these peaks represent the cis-CPAN $\left(m / z 85, t_{\mathrm{r}}=9 \mathrm{~min}\right)$ and trans-CPAN $\left(m / z 85, t_{\mathrm{r}}=14 \mathrm{~min}\right)$ isomers. Considering the $\mathrm{NO}_{y}$ obser- 


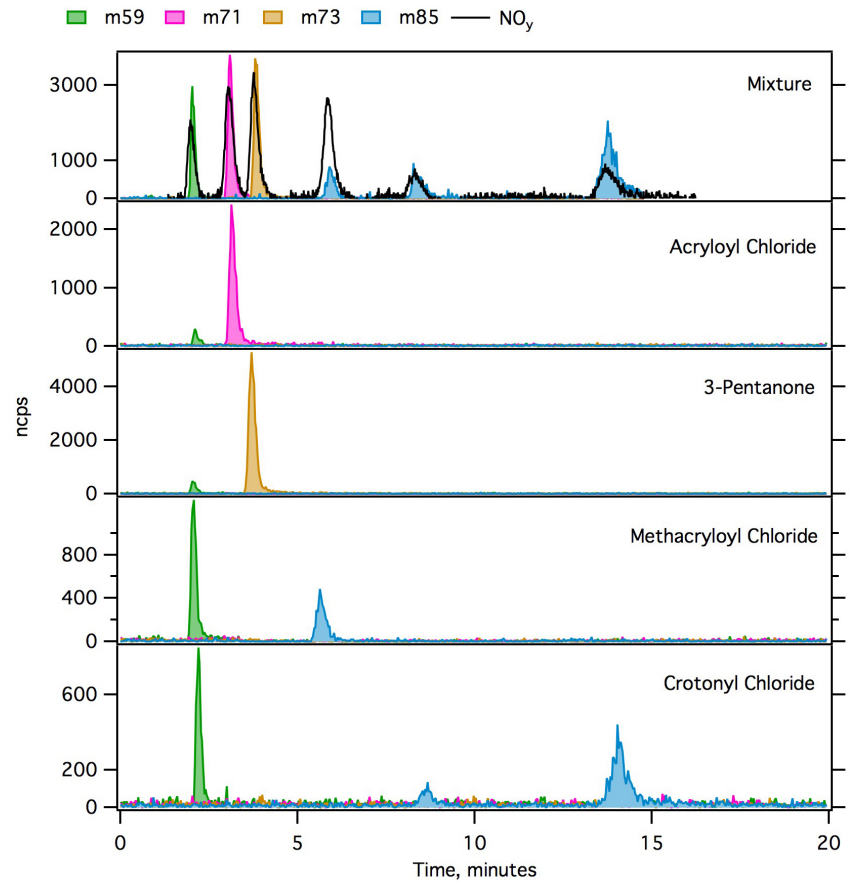

Figure 2. $\mathrm{I}^{-} \mathrm{CIMS}$ and baseline-corrected $\mathrm{NO}_{y}$ measurements are shown for a single GC chromatogram of a calibration mixture containing all four precursor compounds (top panel). $\mathrm{I}^{-}$CIMS measurements of individual calibration mixtures for each of the precursor compounds included in Table 1 (bottom four panels).

vations, (Fig. 2, bottom panel), the CPAN mixture appears to be racemic in the cis and trans isomers as the measured $\mathrm{NO}_{y}$ concentrations for both peaks are nearly identical.

It is important to note that direct sampling of the photolysis source output is not recommended as the reaction produces a large number of undesired byproducts, such as $\mathrm{ClNO}_{2}$ and $\mathrm{Cl}_{2}$. Furthermore, recent work suggests that synthesis of APN standards using acyl chloride compounds should be avoided for reasons of impurities (Tokarek et al., 2014); however, the use of a GC pre-separation step eliminates any possibility of unwanted measurement interferences.

After validation of the photochemistry using singlecomponent mixtures, a multicomponent mixture was prepared containing all five precursor compounds in the volumetric mixing ratios reported in Table 1. In the top panel of Fig. 2, a chromatogram of the products from the multicomponent mixture, measured on both the CIMS and $\mathrm{NO}_{y}$ instruments, is shown. It is clear from these results that mixing the precursor compounds prior to reaction produces no additional, unexpected products. After this initial analysis, the precursor mixture was stored in a laboratory freezer for several months and reanalyzed. While the mixture was observed to yellow over time, no additional reaction products were observed as a result of the long-term storage of the solution. It is noteworthy that the same yellowing was not observed for the long-term storage of individual component mixtures.
The data contained in the top panel of Fig. 2 can be used to determine the sensitivity of $\mathrm{I}^{-}$CIMS to APN detection. The area of each observed peak, measured using CIMS and $\mathrm{NO}_{y}$, was determined by applying an exponentially modified Gaussian peak-fitting routine. After accounting for dilution, the $\mathrm{I}^{-}$CIMS sensitivity $\left(\mathrm{Hz} \mathrm{ppbv}^{-1}\right)$ was determined as the ratio of the CIMS-measured signal to the $\mathrm{NO}_{y}$ concentration for each corresponding peak. Normalized $\left(10^{6} \mathrm{cps} \mathrm{\textrm {I } ^ { - }}\right.$, $m / z$ 127) calibration factors calculated in this manner are reported in Table 1 for each of the APN products observed. Also included in Table 1 are calibration factors reported relative to the measured PAN sensitivity and instrumental detection limits $(3 \sigma)$.

\subsection{Thermo-dissociation of APNs}

In order to probe the sensitivity of the iodide CIMS to the various APN species as a function of dissociation temperature, a series of measurements were made at various inlet dissociator temperatures ranging from 70 to $200^{\circ} \mathrm{C}$. In these experiments, the APN mixture (PAN, APAN, MPAN, PPN, CPAN) was photoreacted, injected onto the GC column, and subsequently analyzed via $\mathrm{I}^{-}$CIMS at various inlet dissociator temperatures. The total inlet flow was $2.2 \mathrm{slpm}$, yielding an inlet residence time of $0.25 \mathrm{~s}$ in the heated region. Unfortunately the gas temperature in the dissociator is not monitored, which would serve as a better metric for the amount of energy in the dissociator than the external temperature reported here.

Eluting peak areas at a given inlet dissociation temperature for each $m / z$ were calculated (Fig. 3a for PAN, $m / z$ 59), normalized to the maximum observed signal throughout the temperature range, and plotted versus inlet dissociator temperature (Fig. 3b). Full thermal-dissociation profiles for the various APN species measured are shown in Fig. 3b. This dependence of TD-CIMS sensitivity on the inlet dissociator temperature has been previously reported in multiple studies (Mielke and Osthoff, 2012; Furgeson et al., 2011; Zheng et al., 2011). The sensitivity dependence reported in this work is specific to this particular inlet design; is largely controlled by a combination of the residence time, temperature, and pressure field in the inlet dissociator; and is system specific. These experiments should be repeated on each individual instrument to better understand the effect of inlet dissociator conditions on measurement sensitivity.

The information in Fig. $3 b$ serves as an aid for determining optimal inlet dissociation temperatures for various applications. In this system, the most efficient detection of PAN, PPN, and APAN corresponds to an inlet temperature of $150{ }^{\circ} \mathrm{C}$. However, for measurement of MPAN and CPAN an inlet dissociation temperature of $130{ }^{\circ} \mathrm{C}$ would result in improved sensitivity. It is an interesting result that the cis and trans isomers of CPAN show a marginally different temperature optimum. These results are consistent with the relative calibrations factors measured (Table 1), where at a thermal- 


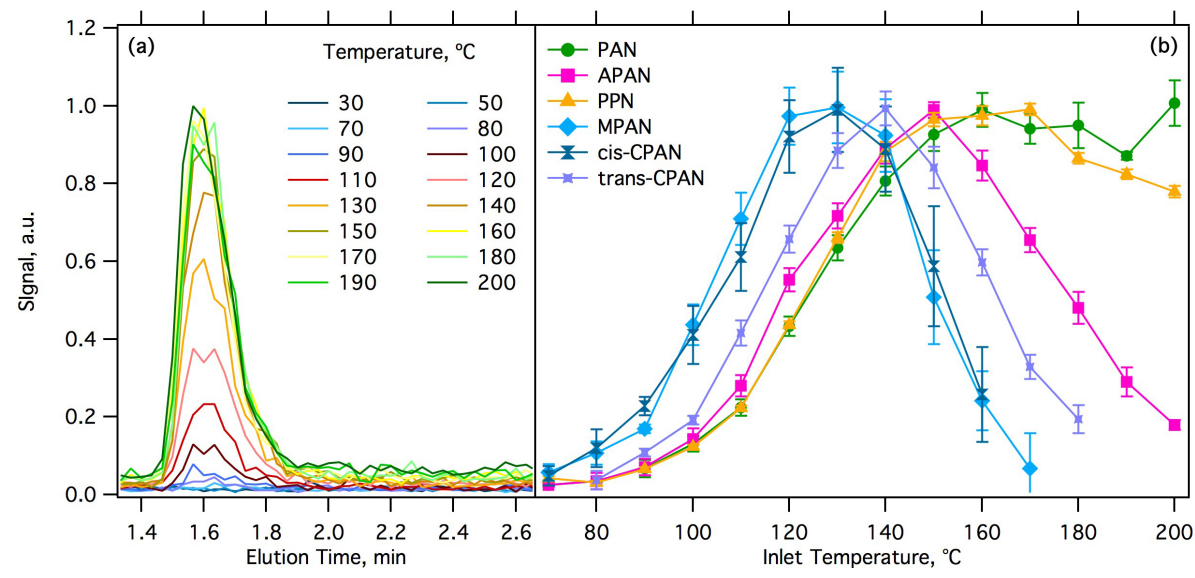

Figure 3. (a) shows the signal observed at $m / z 59$ (PAN) across a range of inlet dissociator temperatures. Fitting the peak areas for each APN produced and plotting the result versus the inlet dissociation temperature yields the figure shown in (b). Thermograms for all of the APNs measured in this work are displayed. Optimal inlet dissociation temperatures of $150^{\circ} \mathrm{C}$ for the detection of PAN, PPN, and APAN and $130^{\circ} \mathrm{C}$ for the detection of MPAN were determined for this system.

dissociation temperature of $150^{\circ} \mathrm{C}$ the detection of transCPAN is more sensitive than cis-CPAN. Similarly, from the temperature profiles in Fig. 3, one would expect PAN, APAN, and PPN to be detected with similar efficiencies at $150^{\circ} \mathrm{C}$, while detection of MPAN should be significantly reduced in comparison. This is clearly reflected in the measured calibration factors displayed in Table 1.

Unfortunately, MPAN is detected at the same product ion as CPAN $(\mathrm{m} / \mathrm{z} 85)$, preventing the attribution of that mass to either species unambiguously. It may however be possible to utilize the inlet dissociation temperature as a method of discrimination between these species. At the concentrations used in this study, operation at an inlet dissociator temperature of $180^{\circ} \mathrm{C}$ would reduce the sensitivity of MPAN to levels below the detection limit while allowing for detection of trans-CPAN. It is therefore possible that periodically modulating the inlet temperature during measurement to $180^{\circ} \mathrm{C}$ could be used as a method of zeroing the MPAN and cisCPAN contributions to $m / z$ 85. Using this method, and assuming a racemic CPAN mixture in the atmospheric, one could potentially determine both MPAN and CPAN (the sum of the cis and trans isomer) concentrations during ambient measurement. Optimization of the inlet dissociator geometry and operating conditions could potentially improve the thermal separation in the relative sensitivities, further aiding in the separation of MPAN and CPAN.

\section{Conclusions}

In this work we have detailed a new method for the production and calibration of APNs. This method provides a simplified alternative to liquid-based synthesis of some of the less-well-studied APN species, e.g., APAN, MPAN, and CPAN. Due to the ease of APN production, it may be possible to improve on the methodology presented here to develop a field-deployable calibration system. Unfortunately, due to impurities formed in the photolysis of acyl chloride compounds this method necessitates the use of a prep-scale GC, which may be limiting. However, this ease of operation and ability to generate simultaneous APN calibrations makes this technique ideal for a laboratory setting. Although not shown here, this method should be compatible with GC-ECD (electron capture detector) systems provided that pre-separation is used to prevent exposure of the ECD system to any chlorinated starting materials and associated photoproducts.

Edited by: G. Phillips

\section{References}

Ciccioli, P., Possanzini, M., Dipalo, V., and Cecinato, A.: Dynamic calibration of peroxyacetyl nitrate (PAN) analyzers by annular denuder and ion-chromatographic techniques, Atmos. Environ. A-Gen., 26, 1513-1518, doi:10.1016/0960-1686(92)901358, 1992.

Darley, E. F., Stephens, E. R., and Kettner, K. A.: Analysis of peroxyacyl nitrates by gas chromatography with electron capture detection, Anal. Chem., 35, 589-591, doi:10.1021/ac60197a028, 1963.

Fehsenfeld, F. C., Dickerson, R. R., Hubler, G., Luke, W. T., Nunnermacker, L. J., Williams, E. J., Roberts, J. M., Calvert, J. G., Curran, C. M., Delany, A. C., Eubank, C. S., Fahey, D. W., Fried, A., Gandrud, B. W., Langford, A. O., Murphy, P. C., Norton, R. B., Pickering, K. E., and Ridley, B. A.: A ground-based intercomparison of $\mathrm{NO}, \mathrm{NO}_{x}$, and $\mathrm{NO}_{y}$ measurement techniques, J. Geophys. Res.-Atmos., 92, 14710-14722, doi:10.1029/JD092iD12p14710, 1987.

Fischer, E. V., Jacob, D. J., Yantosca, R. M., Sulprizio, M. P., Millet, D. B., Mao, J., Paulot, F., Singh, H. B., Roiger, A., Ries, L., 
Talbot, R.W., Dzepina, K., and Pandey Deolal, S.: Atmospheric peroxyacetyl nitrate (PAN): a global budget and source attribution, Atmos. Chem. Phys., 14, 2679-2698, doi:10.5194/acp-142679-2014, 2014.

Flocke, F. M., Weinheimer, A. J., Swanson, A. L., Roberts, J. M., Schmitt, R., and Shertz, S.: On the measurement of PANs by gas chromatography and electron capture detection, J. Atmos. Chem., 52, 19-43, doi:10.1007/s10874-005-6772-0, 2005.

Furgeson, A., Mielke, L. H., Paul, D., and Osthoff, H. D.: A photochemical source of peroxypropionic and peroxyisobutanoic nitric anhydride, Atmos. Environ., 45, 5025-5032, doi:10.1016/j.atmosenv.2011.03.072, 2011.

Gaffney, J. S., Fajer, R., and Senum, G. I.: An improved procedure for high-purity gaseous peroxyacyl nitrate production - use of heavy lipid solvents, Atmos. Environ., 18, 215-218, doi:10.1016/0004-6981(84)90245-2, 1984.

Gaffney, J. S., Bornick, R. M., Chen, Y. H., and Marley, N. A.: Capillary gas chromatographic analysis of nitrogen dioxide and PANs with luminol chemiluminescent detection, Atmos. Environ., 32, 1445-1454, doi:10.1016/s1352-2310(97)00098-8, 1998.

Grosjean, D. and Harrison, J.: Peroxyacetyl nitrate - Comparison of alkaline-hydrolysis and chemi-luminescence methods, Environ. Sci. Technol., 19, 749-752, doi:10.1021/es00138a017, 1985.

Grosjean, D., Fung, K., Collins, J., Harrison, J., and Breitung, E.: Portable generator for on-site calibration of peroxyacetyl nitrate analyzers Anal. Chem., 56, 569-573, doi:10.1021/ac00267a059, 1984.

Grosjean, D., Parmar, S. S., and Williams, E. L.: Time-Averaged measurements of peroxyacetyl nitrate, Environ. Sci. Technol., 25, 1864-1867, doi:10.1021/es00023a003, 1991.

Hansel, A. and Wisthaler, A.: A method for real-time detection of PAN, PPN and MPAN in ambient air, Geophys. Res. Lett., 27, 895-898, doi:10.1029/1999gl010989, 2000.

Hastie, D. R., Gray, J., Langford, V. S., Maclagan, R., Milligan, D. B., and McEwan, M. J.: Real-time measurement of peroxyacetyl nitrate using selected ion flow tube mass spectrometry, Rapid Commun. Mass Spectrom., 24, 343-348, doi:10.1002/rcm.4400, 2010.

Holdren, M. W. and Spicer, C. W.: Field compatable calibration procedure for peroxyacetyl nitrate, Environ. Sci. Technol., 18, 113116, doi:10.1021/es00120a013, 1984.

Horowitz, L. W. and Jacob, D. J.: Global impact of fossil fuel combustion on atmospheric $\mathrm{NO}_{x}$, J. Geophys. Res.-Atmos., 104, 23823-23840, doi:10.1029/1999jd900205, 1999.

Huey, L. G.: Measurement of trace atmospheric species by chemical ionization mass spectrometry: Speciation of reactive nitrogen and future directions, Mass Spec. Rev., 26, 166-184, doi:10.1002/mas.20118, 2007.

Joos, L. F., Landolt, W. F., and Leuenberger, H.: Calibration of peroxyacetyl nitrate measurements with an $\mathrm{NO}_{x}$ analyzer, Environ. Sci. Technol., 20, 1269-1273, doi:10.1021/es00154a014, 1986.

Kravetz, T. M., Martin, S. W., and Mendenhall, G. D.: Synthesis of peroxyacetyl and peroxyaroyl nitrates - Complexation of peroxyacetyl nitrate with benzene, Environ. Sci. Technol., 14, 12621264, doi:10.1021/es60170a014, 1980.

LaFranchi, B. W., Wolfe, G. M., Thornton, J. A., Harrold, S. A., Browne, E. C., Min, K. E., Wooldridge, P. J., Gilman, J. B., Kuster, W. C., Goldan, P. D., de Gouw, J. A., McKay, M., Gold- stein, A. H., Ren, X., Mao, J., and Cohen, R. C.: Closing the peroxy acetyl nitrate budget: observations of acyl peroxy nitrates (PAN, PPN, and MPAN) during BEARPEX 2007, Atmos. Chem. Phys., 9, 7623-7641, doi:10.5194/acp-9-7623-2009, 2009.

Mielke, L. H. and Osthoff, H. D.: On quantitative measurements of peroxycarboxylic nitric anhydride mixing ratios by thermal dissociation chemical ionization mass spectrometry, Int. J. Mass Spectrom., 310, 1-9, doi:10.1016/j.ijms.2011.10.005, 2012.

Moxim, W. J., Levy, H., and Kasibhatla, P. S.: Simulated global tropospheric PAN: Its transport and impact on $\mathrm{NO}_{x}$, J. Geophys. Res.-Atmos., 101, 12621-12638, doi:10.1029/96jd00338, 1996.

Nielsen, T., Hansen, A. M., and Thomsen, E. L.: A convienent method for preparation of pure standards of peroxyacetyl nitrate for atmospheric analysis, Atmos. Environ., 16, 2447-2450, 1982.

Paul, D., Furgeson, A., and Osthoff, H. D.: Measurements of total peroxy and alkyl nitrate abundances in laboratory-generated gas samples by thermal dissociation cavity ring-down spectroscopy, Rev. Sci. Instrum., 80, 114101, doi:10.1063/1.3258204, 2009.

Phillips, G. J., Pouvesle, N., Thieser, J., Schuster, G., Axinte, R., Fischer, H., Williams, J., Lelieveld, J., and Crowley, J. N.: Peroxyacetyl nitrate (PAN) and peroxyacetic acid (PAA) measurements by iodide chemical ionisation mass spectrometry: first analysis of results in the boreal forest and implications for the measurement of PAN fluxes, Atmos. Chem. Phys., 13, 11291139, doi:10.5194/acp-13-1129-2013, 2013.

Ridley, B. A. and Howlett, L. C.: Instrument for nitric-oxide measurements in stratosphere, Rev. Sci. Instrum., 45, 742-746, doi:10.1063/1.1686726, 1974.

Roberts, J. M.: The Atmospheric Chemistry of Organic NItrates, Atmos. Environ. A-Gen., 24, 243-287, doi:10.1016/09601686(90)90108-y, 1990.

Roberts, J. M.: Peroxyacetic Nitric Anhydride (PAN) and Related Compounds, in: Volatile Compounds in the Atmosphere, edited by: Koppmann, R., Blackwell, London, 221-268, 2007.

Roberts, J. M., Stroud, C. A., Jobson, B. T., Trainer, M., Hereid, D., Williams, E., Fehsenfeld, F., Brune, W., Martinez, M., and Harder, H.: Application of a sequential reaction model to PANs and aldehyde measurements in two urban areas, Geophys. Res. Lett., 28, 4583-4586, doi:10.1029/2001g1013507, 2001.

Roberts, J. M., Flocke, F., Chen, G., de Gouw, J. A., Holloway, J. S., Hubler, G., Neuman, J. A., Nicks, D. K., Nowak, J. B., Parrish, D. D., Ryerson, T. B., Sueper, D. T., Warneke, C., and Fehsenfeld, F. C.: Measurement of peroxycarboxylic nitric anhydrides (PANs) during the ITCT 2K2 aircraft intensive experiment, J. Geophys Res.-Atmos., 109, D23S21, doi:10.1029/2004JD004960, 2004.

Roberts, J. M., Marchewka, M., Bertman, S. B., Goldan, P., Kuster, W., de Gouw, J., Warneke, C., Williams, E., Lerner, B., Murphy, P., Apel, E., and Fehsenfeld, F. C.: Analysis of the isoprene chemistry observed during the New England Air Quality Study (NEAQS) 2002 Intensive Experiment, J. Geophys. Res.-Atmos., 111, D23S12, doi:10.1029/2006JD007570, 2006.

Roberts, J. M., Marchewka, M., Bertman, S. B., Sommariva, R., Warneke, C., de Gouw, J., Kuster, W., Goldan, P., Williams, E., Lerner, B. M., Murphy, P., and Fehsenfeld, F. C.: Measurements of PANs during the New England Air Quality Study 2002, J. Geophys. Res.-Atmos., 112, D20306, doi:10.1029/2007JD008667, 2007.

Schrimpf, W., Muller, K. P., Johnen, F. J., Lienaerts, K., and Rudolph, J.: An optimized method for airborne peroxyacetyl 
nitrate (PAN) measurements, J. Atmos. Chem., 22, 303-317, doi:10.1007/bf00696640, 1995.

Singh, H. B., Herlth, D., Ohara, D., Zahnle, K., Bradshaw, J. D., Sandholm, S. T., Talbot, R., Crutzen, P. J., and Kanakidou, M.: Relationship of peroxyacetyl nitrate to active and total odd nitrogen aty northern high-latitudes - Influence of reservoir species on $\mathrm{NO}_{x}$ and $\mathrm{O}_{3}$, J. Geophys. Res.-Atmos., 97, 16523-16530, 1992.

Slusher, D. L., Huey, L. G., Tanner, D. J., Flocke, F. M., and Roberts, J. M.: A thermal dissociation-chemical ionization mass spectrometry (TD-CIMS) technique for the simultaneous measurement of peroxyacyl nitrates and dintrogen pentoxide, J. Geophys. Res.-Atmos., 109, D19315, doi:10.1029/2004JD004670, 2004.

Stephens, E. R.: Smog studies of the 1950s, EOS Transactions of the American Geophysical Union, 68, 89-89, 93, 1987.

Surratt, J. D., Chan, A. W. H., Eddingsaas, N. C., Chan, M. N., Loza, C. L., Kwan, A. J., Hersey, S. P., Flagan, R. C., Wennberg, P. O., and Seinfeld, J. H.: Reactive intermediates revealed in secondary organic aerosol formation from isoprene, P. Natl. Acad. Sci., 107, 6640-6645, doi:10.1073/pnas.0911114107, 2010.

Tanimoto, H., Hirokawa, J., Kajii, Y., and Akimoto, H.: A new measurement technique of peroxyacetyl nitrate at parts per trillion by volume levels: Gas chromatography/negative ion chemical ionization mass spectrometry, J. Geophys. Res.-Atmos., 104, 21343-21354, doi:10.1029/1999jd900345, 1999.

Tokarek, T. W., Huo, J. A., Odame-Ankrah, C. A., Hammoud, D., Taha, Y. M., and Osthoff, H. D.: A gas chromatograph for quantification of peroxycarboxylic nitric anhydrides calibrated by thermal dissociation cavity ring-down spectroscopy, Atmos. Meas. Tech., 7, 3263-3283, doi:10.5194/amt-7-32632014, 2014.

Tuazon, E. C., Graham, R. A., Winer, A. M., Easton, R. R., Pitts, J. N., and Hanst, P. L.: Kilometer pathlength Fourier transform infrared system for study of trace pollutants in ambient and synthetic atmospheres, Atmos. Environ., 12, 865-875, doi:10.1016/0004-6981(78)90024-0, 1978

Tyndall, G. S., Apel, E. C., Williams, E., Flocke, F., Cohen, R., Gilge, S., Kim, S., Milles, G., O’Brien, J., Perring, A., Rappengluck, B., Roberts, J. M., Schmitt, R., Swanson, A., Tanimoto, H., and Wooldridge, P.: PIE 2005: An intercomparison of measurement techniques for peroxyacyl nitrates (PANs), AGU Fall Meeting, San Fransisco, CA, 5 December 2005.
Volz-Thomas, A., Xueref, I., and Schmitt, R.: An automatic gas chromatograph and calibration system for ambient measurements of PAN and PPN, Environ. Sci. Pollut. R., 4, 72-76, 2002.

Warneck, P. and Zerbach, T.: Synthesis of peroxyacetyl nitrate in air by acetone photolysis, Environ. Sci. Technol., 26, 74-79, doi:10.1021/es00025a005, 1992a.

Warneck, P. and Zerbach, T.: Synthesis of Peroxyacetyl Nitrate in Air by Acetone, Environ. Sci. Technol., 26, 74-79, doi:10.1021/es00025a005, 1992b.

Williams, J., Roberts, J. M., Fehsenfeld, F. C., Bertman, S. B., Buhr, M. P., Goldan, P. D., Hubler, G., Kuster, W. C., Ryerson, T. B., Trainer, M., and Young, V.: Regional ozone from biogenic hydrocarbons deduced from airborne measurements of PAN, PPN, and MPAN, Geophys. Res. Lett., 24, 1099-1102, 1997.

Williams, J., Roberts, J. M., Bertman, S. B., Stroud, C. A., Fehsenfeld, F. C., Baumann, K., Buhr, M. P., Knapp, K., Murphy, P. C., Nowick, M., and Williams, E. J.: A method for the airborne measurement of PAN, PPN, and MPAN, J. Geophys. Res.-Atmos., 105, 28943-28960, doi:10.1029/2000jd900373, 2000.

Wooldridge, P. J., Perring, A. E., Bertram, T. H., Flocke, F. M., Roberts, J. M., Singh, H. B., Huey, L. G., Thornton, J. A., Wolfe, G. M., Murphy, J. G., Fry, J. L., Rollins, A. W., LaFranchi, B. W., and Cohen, R. C.: Total Peroxy Nitrates (?PNs) in the atmosphere: the Thermal Dissociation-Laser Induced Fluorescence (TD-LIF) technique and comparisons to speciated PAN measurements, Atmos. Meas. Tech., 3, 593-607, doi:10.5194/amt-3-5932010, 2010.

Yokelson, R. J., Crounse, J. D., DeCarlo, P. F., Karl, T., Urbanski, S., Atlas, E., Campos, T., Shinozuka, Y., Kapustin, V., Clarke, A. D., Weinheimer, A., Knapp, D. J., Montzka, D. D., Holloway, J., Weibring, P., Flocke, F., Zheng, W., Toohey, D., Wennberg, P. O., Wiedinmyer, C., Mauldin, L., Fried, A., Richter, D., Walega, J., Jimenez, J. L., Adachi, K., Buseck, P. R., Hall, S. R., and Shetter, R.: Emissions from biomass burning in the Yucatan, Atmos. Chem. Phys., 9, 5785-5812, doi:10.5194/acp-9-5785-2009, 2009.

Zheng, W., Flocke, F. M., Tyndall, G. S., Swanson, A., Orlando, J. J., Roberts, J. M., Huey, L. G., and Tanner, D. J.: Characterization of a thermal decomposition chemical ionization mass spectrometer for the measurement of peroxy acyl nitrates (PANs) in the atmosphere, Atmos. Chem. Phys., 11, 6529-6547, doi:10.5194/acp-11-6529-2011, 2011. 